\title{
Ecosystem approaches to health and knowledge-to-action: towards a political ecology of applied health-environment knowledge
}

\author{
Ben W. Brisbois a 1 \\ Andrés Burgos Delgado ${ }^{\mathrm{b}}$ \\ Douglas Barraza ${ }^{c}$ \\ Óscar Betancourt ${ }^{\mathrm{d}}$ \\ Donald Cole $^{\text {a }}$ \\ Maya Gislason ${ }^{\text {e }}$ \\ Frédéric Mertens ${ }^{\mathrm{b}}$ \\ Margot Parkes ${ }^{\mathrm{f}}$ \\ Johanne Saint-Charles ${ }^{\mathrm{g}}$ \\ ${ }^{\text {a }}$ University of Toronto, Canada \\ ${ }^{\mathrm{b}}$ Universidade de Brasília, Brazil \\ c National University of Costa Rica, Costa Rica \\ ${ }^{\mathrm{d}}$ Fundación Salud Ambiente y Desarrollo, Ecuador \\ e Faculty of Health Sciences, Simon Fraser University, Canada \\ ${ }^{\mathrm{f}}$ University of Northern British Columbia, Canada \\ g Université du Québec à Montréal, Canada
}

\begin{abstract}
Political ecology pushes back against the apolitical and ahistorical ecologies frequently found in mainstream scientific accounts of nature and the environment, and has increasingly focused on how scientific knowledge is 'socially constructed.' In this article, we argue for political ecological engagement with the highly influential knowledge-to-action (KTA) movement in science about health and the environment. We introduce KTA using results of a survey conducted under the auspices of a Canada-Latin America-Caribbean 'ecosystem approaches to health' (ecohealth) collaboration, and then narrow our focus to a single illustrative ecohealth project, dealing with the health impacts of small-scale gold mining in southwestern Ecuador. We employ an ecology of knowledge framework for integrating insights from science and technology studies,

\footnotetext{
${ }^{1}$ Dr. Ben Brisbois, Postdoctoral Fellow, St. Michael's Hospital and Dalla Lana School of Public Health, University of Toronto, Canada. Email: bwbrisbois "at" alumni.ubc.ca. Dr. Andrés Burgos Delgado, Center for Sustainable Development, Universidade de Brasília, Brazil. Dr. Douglas Barraza, Central American Institute for Studies on Toxic Substances (IRET), National University of Costa Rica, Costa Rica. Dr. Óscar Betancourt, Fundación Salud Ambiente y Desarrollo, Ecuador. Prof. Donald Cole, Dalla Lana School of Public Health, University of Toronto, Canada. Dr. Maya Gislason, Faculty of Health Sciences, Simon Fraser University. Dr. Frédéric Mertens, Center for Sustainable Development, Universidade de Brasília, Brazil. Dr. Margot Parkes, School of Health Sciences, University of Northern British Columbia, Canada. Prof. Johanne Saint-Charles, Centre de recherche interdisciplinaire sur le bien-être, la santé, la société et l'environnement (CINBIOSE), Université du Québec à Montréal, Canada. Acknowledgements: The research reported in this paper was made possible by the Pan-American partnership for the strengthening of research, policy and practice at the intersection of health, ecosystems and society (EkoSanté Collaboration), with financial support from the International Development Research Centre. Valuable contributions to the EkoSanté project and this article were made by Dr. Kendra Mitchell-Foster.
} 
illustrating the interacting actors, material artifacts, institutions and discourses involved in not only the generation but also the application of health-environment science. The origins of ecohealth research in the Americas reflect interacting epistemological and political factors, as sophisticated, complex systemic analyses of health-environment interactions occurred amidst increasing neoliberalization of knowledge production. Simultaneously, corporate actors such as large mining companies influenced both the distribution of healthdamaging environmental conditions in the Americas, and the ways in which they were studied. This analysis motivates our advocacy of specifically political ecologies of health-environment knowledge, in which inequitable power dynamics and non-human actors are foregrounded in studies of the social production and application of science. The political ecology of knowledge framework that we envision would allow for simultaneous consideration of how societal contexts influence scientific knowledge production, and how the resulting knowledge can be better applied to protect the health of communities facing environmental injustice.

Key words: ecohealth; mining; praxis; science and technology studies; knowledge-to-action; Canada; Ecuador

\section{Résumé}

L'écologie politique remet en question las explications apolitiques et anhistoriques fréquemment rencontrées dans les compte-rendu scientifiques sur la nature et l'environnement et met de plus en plus l'accent sur la manière dont la connaissance scientifique est socialement construite. Dans cet article, nous soutenons la pertinence de l'écologie politique pour le mouvement « du savoir à l'action », très influent dans les sciences de la santé de l'environnement. Nous présentons la perspective « du savoir à l'action » en nous appuyant sur les résultats d'une enquête menée dans le cadre d'une collaboration Canada-Amérique latine et Caraïbes sur les approches écosystémiques à la santé (écosanté), pour ensuite concentrer notre attention sur un unique projet écosanté, qui porte sur les effets sur la santé de l'extraction de l'or à petite échelle dans le sud-ouest de l'Équateur. Nous employons un cadre conceptuel d'écologie de la connaissance pour intégrer les idées des études en science et technologie et illustrons les interactions entre les actrices et acteurs, les artefacts matériels, les institutions et les discours impliqués non seulement dans la génération, mais aussi dans la reproduction de la science en santé et environnement. Les origines de la recherche en écosanté dans les Amériques reflètent l'interaction entre des facteurs épistémologiques et politiques, tandis que les analyses systémiques complexes et sophistiquées des interactions entre santé et environnement se sont déroulées dans un climat croissant de néolibéralisation de la production de connaissances. En parallèle, les acteurs corporatifs telles les grandes sociétés minières ont influencé tout autant la répartition des conditions environnementales nuisibles à la santé dans les Amériques que la façon dont elles ont été étudiées. Cette analyse motive notre défense d'une écologie spécifiquement politique de l'application de la connaissance en santé et environnement, au sein de laquelle les dynamiques inégales de pouvoir et les facteurs non humains sont mis de l'avant dans les études sur la production et l'application sociales de la science. Un cadre de l'écologie politique de la connaissance, comme nous proposons, permettrait de tenir compte simultanément de la manière dont les contextes sociétaux influencent la production de connaissances scientifiques et de la manière dont ces connaissances peut être mieux appliqués pour protéger la santé des communautés face à l'injustice environnementale.

Mots clés: écosanté; exploitation minière; praxis; études des science et technologie; du savoir à l'action; Canada; Équateur

\section{Resumen}

La ecología política desafía a las ecologías apolíticas y ahistóricas que se sitúan con frecuencia en los postulados científicos de la naturaleza y el medio ambiente, y se ha centrado cada vez más en cómo se construye socialmente el conocimiento científico. En este artículo abogamos por un compromiso de la ecología política con el influyente movimiento ."conocimiento para la acción" (KTA por sus siglas en inglés) en la ciencia sobre la salud y el medio ambiente. Presentamos el KTA usando los resultados de una encuesta realizada en el ámbito de una colaboración Canadá-América Latina y el Caribe de "enfoques ecosistémicos en salud" (ecosalud) y, a continuación, dirigimos nuestra atención sobre un proyecto ilustrativo de ecosalud que trata sobre los efectos en la salud y el ambiente por la minería del oro a pequeña escala en el suroeste de Ecuador. Empleamos un marco analítico de la ecología del conocimiento para integrar las percepciones derivadas de los estudios de ciencia y de tecnología, ilustrando los agentes que interactúan, los artefactos materiales y las instituciones y discursos involucrados no solo en la generación, sino también en la aplicación de la ciencia salud-ambiente. Los orígenes de la investigación en ecosalud en las Américas reflejan la 
interacción de factores epistemológicos y políticos como sofisticados y complejos análisis sistémicos de las interacciones salud-ambiente ocurridas en medio de la creciente neoliberalización de la producción del conocimiento. Al mismo tiempo, agentes empresariales, tales como grandes empresas mineras, influyeron tanto en la alteración de las condiciones ambientales perjudiciales para la salud en las Américas como en la forma en que los impactos se estudiaron. Este análisis motiva nuestra defensa específica de la aplicación de las ecologías políticas del conocimiento salud-ambiente en aquellos casos en los cuales dinámicas de poder no equitativas y agentes no humanos son colocados en primer plano en los estudios de la producción social y en la aplicación de la ciencia. El marco de la ecología política del conocimiento que proponemos permite considerar simultáneamente cómo los contextos sociales influyen sobre la producción del conocimiento científico, y cómo el conocimiento resultante se puede aplicar de mejor manera para proteger la salud de las comunidades que enfrentan la injusticia ambiental.

Palabras clave: ecosalud; minería; praxis; estudios de ciencia y tecnología; conocimiento para la acción; Canadá; Ecuador

\section{Resumo}

A ecologia política desafia às ecologias apolíticas e ahistóricas que se situam frequentemente nos postulados científicos da natureza e do meio ambiente, e tem-se centrado cada vez mais em como o conhecimento científico é socialmente construído. Neste artigo defendemos o compromisso da ecologia política com o influente movimento ."conhecimento para a ação" (KTA, pelas suas siglas em inglês) na ciência sobre a saúde e o meio ambiente. Apresentamos o KTA usando os resultados de uma enquete realizada no âmbito de uma colaboração Canadá-América Latina e Caribe de ."enfoques ecossistêmicos em saúde" (ecosaúde) e, em seguida, colocamos nossa atenção em um projeto ilustrativo de ecosaúde que trata dos efeitos na saúde da mineração de ouro em pequena escala no sudeste do Equador. Usamos um marco analítico de ecologia do conhecimento para integrar as percepções que provém dos estudos de ciência e de tecnologia, ilustrando os agentes que interagem, os artefatos materiais e as instituições e discursos envolvidos não só na geração, senão também na aplicação da ciência saúde-ambiente. As origens da pesquisa em ecosaúde nas Américas refletem as interações de fatores epistemológicos e políticos como sofisticados e complexos análises sistémicos das interações saúde-ambiente que aconteceram no meio da crescente neoliberalização da produção do conhecimento. Ao mesmo tempo, agentes empresarias, tais como grandes empresas mineradoras, influíram tanto na alteração das condições ambientais prejudiciais para a saúde nas Américas quanto na forma em que os impactos se estudaram. Esta análise motiva nossa defesa específica da aplicação das ecologias politicas do conhecimento saúde-ambiente naqueles casos nos quais dinâmicas de poder não equitativas e agentes não humanos são colocados no primeiro plano nos estudos sobre a produção social e a aplicação da ciência. O marco da ecologia política do conhecimento permite considerar simultaneamente como os contextos sociais influenciam a produção do conhecimento científico, e como o conhecimento resultante pode ser melhor utilizado para proteger a saúde das comunidades que enfrentam a injustiça ambiental.

Palavras-chave: ecosaúde; mineração; práxis; estudos de ciência e tecnologia; conhecimento para a ação; Canadá; Equador

\section{Introduction}

In this article, we analyze the social production of knowledge and efforts to achieve greater societal impact within the EkoSanté collaboration, a network of North, Central and South American researchers and practitioners focused on ecosystem approaches to human health ('ecohealth'). Political ecology has increasingly sought to understand the social production of environmental science, complementing its understandings of political economic influences on the environment and resource use, and of competing environmental narratives (Goldman et al. 2011). In particular, recent years have seen engagement with the multidisciplinary field of science and technology studies (STS), which presents a well-developed suite of methods and concepts for understanding the interacting material artifacts and practices, pre-existing knowledges and social relationships that figure in the generation of scientific knowledge (Hackett et al. 2008). Contributors to an edited book combining political ecology and STS document "the multiplicity of environmental knowledges; the joint production of nature and society; and the packaging, transport, and translation of knowledge" (Goldman and Turner 2011: 21). In addition to such insights that STS can bring to political ecology, the latter field's explicit social justice orientation has the potential to overcome an apparent 
reluctance in much STS work to grapple with major inequities in society such as legacies of colonialism and processes of neoliberalization (Birch 2013; Goldman and Turner 2011; Sismondo 2008). Political ecology's frequent 'engaged' aspirations to apply scholarship to the redress of environmental injustice (Blaikie 2012; Dwyer and Baird 2014; Rocheleau 2008; Martinez-Alier et al. 2014; Walker 2006) suggest an opportunity to put STS-informed analyses to work on behalf of marginalized groups. Lave (2012: 32), for example, moves from neoliberalism's impacts on the generation of environmental knowledge to the need for activist responses on the part of political ecologists, arguing that "the neoliberalization of knowledge production has social justice implications that extend far beyond our livelihoods."

In parallel to this engagement with STS, political ecologies of disease and health have, for decades, examined connections between environmental change, political economy, and implications for human health (Connolly et al. 2017; Jackson and Neely 2015; King 2015). In addition to showing how political economic factors affect local environments and related health outcomes, political ecologies of health frequently unpack discursive claims about health and the environment (e.g. McSweeney and Pearson 2013; Neely 2015). Jackson and Neely (2015) extend this discursive focus by drawing on multiple social scientific fields including STS - to advocate for political ecologies of health in which all knowledge is understood as 'situated', or socially produced. Beyond this important recommendation, however, political ecologies of health have yet to draw substantially on STS's conceptual and methodological toolkit in exploring how knowledge about health-environment relationships is socially constructed (but see Galt 2011). Political ecologies of health also do not yet appear to have thoroughly explored how their important findings can be applied to the actual redress of health problems related to environmental injustice.

We argue here that applied fields such as ecohealth, in which 'knowledge-to-action' (KTA) efforts explicitly aim to improve environmentally-linked health outcomes in communities or populations, represent an important focus for future political ecologies of health and associated efforts to understand the social construction of health-environment knowledge. To substantiate this claim, we apply an ecology of knowledge framework (Rosenberg 1979) to integrate insights from STS in analyzing ecohealth knowledge generation and related KTA efforts. We also explore how the framework could be enhanced by political ecology approaches, with the objective of promoting explicitly political ecologies of health-environment knowledge. Importantly, we write as members of a network - the EkoSanté collaboration - that has emerged from a shared history of working within and across regions and countries (Parkes et al. 2012), seeking to better understand the origins and potential impacts of our field. Our engagement with political ecology and STS accordingly uses language intended to be accessible to scientists interested in relationships between ecosystems, societies and human health.

The article proceeds as follows. First, we briefly review critical scholarship on knowledge-to-action in health, pointing out resonances with political ecology insights. Next, we present the EkoSanté collaboration as an example of contemporary KTA efforts at least partially informed by such critical scholarship, using results of a survey carried out in 2015 with fellow EkoSanté members. These survey results illustrate a preliminary, but increasing, attention to political power and social influences on science among ecohealth researchers. Picking up from these suggestive themes, we then employ a graphical heuristic for the ecology of knowledge framework (Akera 2007) to explore the social production - and social impacts - of ecohealth research, including the field's evolving perspectives on KTA and political economic power. We focus in on a single illustrative ecohealth project, examining health impacts of small-scaling gold mining in Ecuador, to explore how political economy, narratives and material objects interact in the generation, and application, of scientific knowledge on health and the environment. We end by discussing avenues to enhance the use of STS in political ecology, and to apply the results in efforts by communities and scientists (social, health and environmental) to advance environmental justice through better-informed KTA.

\section{Knowledge-to-action in public health}

KTA, broadly-speaking, is an outgrowth of the 'evidence-based medicine' (EBM) and later evidencebased policy movements, through which physicians, epidemiologists and others have sought to ensure that clinical practice and health-related policymaking are informed by the best-available science (Mykhalovskiy and Weir 2004; Pope 2003). A template for the EBM movement was provided by Scottish epidemiologist 
Archie Cochrane, who in the early 1970s advocated randomized controlled trials (RCTs) as the 'gold standard' of proof in medical science. Denny (1999) characterizes EBM as an attempt to shore up the declining authority of the medical profession in the late $20^{\text {th }}$ century. Evidence-based approaches were significantly popularized in the 1990s by researchers and physicians at the University of Oxford and Canada's McMaster University, facilitated by new computing technologies and accompanied by development of techniques such as systematic reviews and meta-analyses for rigorously evaluating and combining the results of predominantly clinical epidemiology studies (Denny 1999; Mykhalovskiy and Weir 2004). From these beginnings, evidencebased thinking has permeated more generally, and internationally, throughout public health and public policy (de Leeuw, McNess, Crisp and Stagnitti 2008; Greenhalgh and Russell 2009). For example, evidence-based thinking is widely acknowledged as the overwhelmingly dominant frame in the large and growing field of global health (Adams 2013; McInnes and Lee 2012).

Early critiques of evidence-based approaches highlighted their often-simplistic vision of how health science is imagined to translate into improved health, such as 'contagion' models assuming that 'infecting' society with evidence will lead to desired results (de Leeuw et al. 2008; Greenhalgh et al. 2005). Another recurring critique is that evidence-based approaches delegitimize all ways of knowing other than a small number of epidemiological study designs, especially RCTs, with a consequent loss of important information and silencing of marginalized voices (Holmes et al. 2006; Mykhalovskiy et al. 2008). Adams (2013: 55) further illustrates how the imposition of epidemiologic standards of evidence has facilitated the commercialization of knowledge in global health by creating a "platform for the buying and selling of truth and reliability." Perhaps most profoundly, the origins of evidence-based approaches in the global North raise the prospect that their extension to LMICs represents a neo-colonial imposition of Northern priorities on Southern actors (Behague et al. 2009).

Responding in part to such critiques, contemporary KTA scholarship provides for more inclusive definitions of 'evidence' within integrative, systems-focused and iterative strategies for improving health through application of scientific knowledge (Best and Holmes 2010; Bowen and Graham 2013). In spite of increasingly nuanced and context-sensitive strategies for moving from knowledge to action, however, persistent - and politically fraught - obstacles persist. A recent review of health KTA frameworks found the majority to contain minimal consideration of health equity, or the avoidance of unfair health disparities across social groups (Davison et al. 2015). In addition, many of the interventions suggested by health research conflict with the policy commitments of the world's most powerful countries, and numerous lower and middle income countries (LMICs) coerced by international financial institutions to adopt similar neoliberal policies (Labonte et al. 2005). Such observations resonate with political ecology's perennial effort to push back against the apolitical and ahistorical ecologies frequently found in mainstream scientific accounts of nature and the environment (Robbins 2012). KTAs focus on understanding and improving the generation and application of health knowledge, furthermore, is suggestively paralleled by political ecologists' use of STS to understand the "production, application and circulation" of knowledge about the environment (Goldman and Turner 2011: 15). Political ecologies of health, however, have not yet specifically engaged with evidencebased approaches in public health or medicine, in spite of the dominance of evidence-based reasoning. We therefore proceed to illustrate an initiative, EkoSanté, that is informed by the critical KTA scholarship reviewed above and that aims to achieve better application of health and environmental science to the redress of health and environment inequities. We then apply an ecology of knowledge framework to one project drawn from EkoSanté, using insights from STS to clarify key opportunities for political ecological exploration of the social construction of applied health-environment knowledge.

\section{Contemporary perspectives on knowledge-to-action: Ecohealth and the EkoSanté collaboration}

Ecosystem approaches to health (ecohealth) emerged in multiple forms as a field of study and practice in the late- $20^{\text {th }}$ century, broadly focusing on the implications of ecosystems and ecological change for human health (Forget and Lebel 2001; Waltner-Toews 2001; Wilcox et al. 2004). Beginning in the mid 1990s, a dedicated funding stream of the International Development Research Centre (IDRC), a Canadian Crown 
Corporation, has been influential in the development and evolution of ecohealth (Cole et al. 2006). IDRC Ecohealth projects initially consisted of action-research initiatives in the global South aimed at improving human health through environmental management, based on 'pillars' of transdisciplinarity (non-hierarchical integration of different disciplinary and community knowledges), multi-stakeholder participation and attention to gender and other equity concerns (Lebel 2003). These three pillars were later expanded to include explicit attention to complex systems thinking, sustainability and knowledge-to-action (Charron 2012). Expanding on the pillar of KTA, Charron describes ecohealth as "an applied process of inquiry predicated on the principle of knowledge-to-action...[aiming] to achieve evidenced-based change in the health and wellbeing of people, at least partly through improved environmental conditions or better interactions with ecosystems" (2012: 256).

While not the only example of ecosystem approaches to health, the IDRC Ecohealth Program Initiative illustrates and integrates prominent trends in ecohealth thinking, and has also played a major role in building the ecohealth field through funding contributions to a variety of training programs, communities of practice, international conferences, the International Association for Ecology and Health, and the journal EcoHealth. Ecohealth has been recognized as a Canadian public health milestone by the Canadian Institutes for Health Research Institute of Population and Public Health and by the Canadian Public Health Association (Webb et al. 2010), and was recently identified as a KTA framework devoting significant attention to health equity (Davison et al. 2015).

IDRC-produced books illustrate the diverse range of topics and fascinating cast of characters involved in ecohealth research in the Americas (Lebel 2003; Charron 2012). ${ }^{2}$ In the Brazilian Amazon, the health of riverine communities was found to be compromised, not by gold mining as initially suspected, but by transport of mercury from deforested soils into rivers and up aquatic food webs to people (Guimarães and Mergler 2012). In Mexico, ecosystem management accomplished control of malaria-transmitting mosquitoes without recourse to DDT (Lebel 2003), while community-based efforts helped to control dengue's mosquito vector in Cuba (Bonet et al. 2007). In Ecuador, investigators documented toxic exposures generated by interactions between flowers, pests, pesticides and workers, leading to agricultural certification systems, pesticide control policies and even support for the inclusion of a 'right to health' in Ecuador's Constitution (Breilh 2012).

While the scholarship reviewed in this article's introduction suggests major problems with simplistic evidence-based strategies, encouraging examples exist of IDRC-funded ecohealth projects leading to policy change. For example, the technologies and municipal policies generated by the Puyango study were paralleled development of 'healthy public policies' to prevent pesticide exposure in highland Ecuadorian potato production (Orozco and Cole 2012). Such societal impacts were typically the result of multi-year actionresearch processes, with considerable efforts to engage communities and policymakers. However, a recurring theme in ecohealth scholarship involves major challenges faced when seeking to achieve such real-world impact, frequently due to the influence of corporate power on public policy processes. Based on their experience attempting to improve pesticide management practices among Ecuadorian potato farmers, for example, Cole et al. (2006: I12) conclude that the ecohealth program's "holistic, almost transcendent systems' frameworks" need modification if they are to adequately grapple with macroeconomic dynamics and the powerful corporate actors driving them (on the need for more attention to political and economic power in ecohealth, see also Dakubo 2011; Ráez-Luna 2008).

While the IDRC's ecohealth programming is - at the time of writing - formally winding down, its funding of the EkoSanté collaboration represents an explicit attempt to learn from its decades of ecohealth funding, in particular with respect to the challenge of KTA, or achieving real-world health benefits based on research results. EkoSanté is a partnership between communities of practice in ecosystem approaches to

\footnotetext{
${ }^{2}$ We refer to these official IDRC publications at various times throughout this article. We note that the editors of these publications were working in their capacity as IDRC employees, responding to a number of institutional and political pressures. Our critical comments are therefore directed at the institutional character of these texts, and not at any authors or editors personally.
} 
health in Canada (CoPEH-Canada), and in Latin America and the Caribbean (CoPEH-LAC) and therefore includes a range of projects and initiatives spanning the Americas (http://ekosante.uqam.ca/en). ${ }^{3}$

The EkoSanté survey was designed to document and improve interactions at the nexus of research, policy change, and concrete actions and practices. An initial 2013 workshop in Suchitoto, El Salvador and subsequent efforts by a working group and two trainees $(B B$ and $A B$ ) generated a survey to gather data from researchers and practitioners in the Americas working on health-environment-society linkages. After the survey was piloted in late 2014, ethics approval was received from the Université du Québéc à Montréal. The online survey could be completed in either English or Spanish, and was advertised to members of CoPEHLAC and CoPEH-Canada. Final survey administration occurred in April-June, 2015, either on-line or through face-to-face or phone/skype interviews by the first author. The unit of analysis for the survey was a research or intervention project, and participants were encouraged to complete the survey once per relevant project they had carried out. A total of 39 complete survey responses were received from 38 different participants, one of whom entered two different projects. Fourteen responses were in Spanish, and 25 were in English. Five of the English responses were gathered through phone, skype or in-person interviews with members of CoPEH-Canada. No members of CoPEH-LAC completed the survey via the interview mechanism, but several entered their on-line responses in English. Data gathered included basic project details, while more in-depth questions, both close- and open-ended, gathered data about the relationship between research, actions/practices and policy. Analysis of textual data from open-ended questions used Nvivo (v10), and moved from identification of text dealing with research-policy-practice interactions, to coding of specific emergent themes.

\section{The nexus of research, policies and practices}

We now substantiate three main themes that emerged in our analysis of the EkoSanté survey results. These involve:

(a) tension between community participation and behavior-change objectives,

(b) positive perspectives on KTA, and

(c) critical/structural perspectives on KTA.

The survey results reflected (a) tension between community participation and behavior-change objectives, both between and within projects. Numerous descriptions of EkoSanté members' projects, for example, featured researchers changing the knowledge or behaviors of others. The 'others' in question sometimes included other researchers, policymakers or frontline health workers, but often included Latin American peasants, workers, and community members to whom research efforts could provide new and better information and ways of being healthy. For example, one project sought to promote "rational use of water", while another described workshops held "so that the affected people change their habits, improving their quality of life." Consistent with ecohealth's core focus on community participation, in contrast, were projects involving communities in research or intervention processes. For example, numerous initiatives were developed based on community priorities, as in one project examining problems "identified through a workshop with inter-sectoral and community participation." Multiple projects, however, demonstrated an intriguing blend of behavior-change and community participation goals, illustrating a possible tension

\footnotetext{
${ }^{3}$ The EkoSanté collaboration involves ecohealth researchers and practitioners from across Canada (CoPEH-Canada is a pan-Canadian initiative), and across the six different regional 'nodes' of CoPEH-LAC (Mexico, Brazil, Central America and the Caribbean, Andean Region, Southern Cone, and a Canadian node at the Université du Québec à Montréal). While involving multiple countries and institutions, EkoSanté does not represent the entirety of ecohealth work in these regions, and also does not include ecohealth researchers and practitioners in the USA. The projects represented span the Americas but cannot be considered representative.
} 
between wanting to change knowledges or behaviors, and also seeking to employ participatory methods and culturally appropriate strategies:

The...project aims to enhance and strengthen collaboration and networking between and within non-government and government agencies, and communities...with a focus on healthy eating, active living and literacy; and with an overall objective of [community members] following healthier lifestyles.

Overlapping with both community-participation and behavior-change goals, another common theme demonstrates what we term a (b) positive perspective on KTA. Comments of this nature were consistent with the view (underlying all evidence-based approaches) that research can and should inform changes in policy or practice and lead to health benefits for vulnerable populations. Evidence of this widespread belief is found in the large number of projects whose objectives included real-world impacts, in addition to simple generation of new scientific knowledge. For example, one project's definition of success indicated that "knowledge acquired through action-research [should be] transformed into concrete practices in health programs, with participation of different sectors, organizations and stakeholders, to influence new policies."

Often in contrast to such perspectives, however, was another frequently expressed theme involving (c) critical or structural perspectives on KTA. These perspectives often reacted to a perceived widespread (blind) faith that research would or could inform real-world changes, described by one participant as "that utopic dream that [research] would lead to action on the ground." A more comprehensive expression of this critical perspective was provided by another participant:

Always interesting to ask researchers about changing public policy because they don't have a mandate...they just speak truth to power. Just articulating this, the ecohealth community can be a bit naïve in using the word policy and changing public policy. It's important that we are a little more realistic in terms of what research does, in terms of how public policy is made.

Such critical perspectives were also frequently accompanied by more structural arguments about how real change in policy or practice tends to be accomplished: as one participant explained, "policy tends to reflect the interests of political-economic power relations, rather than research evidence." This individual went on to comment on university-related institutional barriers to effective KTA:

My project was a $\mathrm{PhD}$ dissertation, so research had to be my first priority. I found that affecting policy and practices (e.g. through a participatory approach) was less feasible within the timelines and requirements I was faced with as a graduate student.

Positive and critical/structural perspectives on KTA were not mutually exclusive themes. A small number of participants attempted to avoid simplistic KTA models, without rejecting outright the possibility of changing policies or practices to improve health. One participant described how the passage of a national law based on her research results was enabled by the fact that the government at the time was facing a controversy and the parliament was relatively empty on the day of the vote. Another participant found that "inequitable distribution of power among Health Authority corporate and medical officers" was preventing effective collaborative action on health-environment issues. Many participants therefore incorporated critical/structural arguments, and sometimes recognition of the institutional dynamics of academia or public health, into a nevertheless optimistic view of KTA. In some cases, researchers even began to engage with large-scale political economic considerations, though usually in a way that was 'off the side of their desks' and not integrated within conventional ecohealth projects. 
Thus EkoSanté projects reflect conventional and more complex or critical visions of KTA in engaging with environments and communities in the Americas. We now extend on these reflections and critical perspectives using an ecology of knowledge framework and a single illustrative ecohealth project entered in the survey to bring multiple STS insights to bear on KTA efforts in ecohealth. This characterization allows us to outline a specifically political ecological approach to understanding the social production, application and circulation of health-environment knowledge.

\section{An ecology of knowledge case study: the Puyango project}

The ecology of knowledge metaphor was elaborated by the historian Charles Rosenberg $(1979,1988)$ as a way of understanding how scientific knowledge evolves over time through internal disciplinary debates and developments, but also in connection with external social and political contexts. ${ }^{4}$ The concept, when extended, provides a useful framework for systematically integrating and visualizing numerous insights from STS, especially related to multi-scalar science-society interactions (cf. Taylor 1990, 2011). Importantly, we note that Rosenberg employed an ecology metaphor to explore science-society relationships, whereas the field of political ecology tends to refer to ecology as a science, or source of empirical data (although not one whose claims are taken uncritically). ${ }^{5}$ Our decision to employ a framework inspired by Rosenberg's ecology of knowledge metaphor is motivated by our understanding of political ecology as 'a community of practice and...a certain kind of text' (Robbins 2012: 5, emphasis in original). Robbins's well-known definition of what such texts typically describe - "the condition of change of social/environmental systems, with explicit consideration of relations of power" (p. 20) - does not extend to how such texts might systematically account for the social production of scientific knowledge about social/environmental systems. We therefore settled on the ecology of knowledge framework as a helpful extension of the "certain kind of text" typically produced by political ecologists, albeit one with the potential to induce confusion over whether ecology is being treated as a metaphor or a science. We return to the hopefully-productive tension between these two uses of 'ecology' in the article's concluding sections.

While in-depth ecology of knowledge analyses have been carried out by sociologists of science (e.g. Star 1995), in this article we employ Akera's (2007) graphical heuristic framework for historians. Elements relevant to the production of knowledge are understood to interact both within and across eight 'layers'.

(1) Actors (e.g. individual scientists);

(2) Artifacts such as laboratory apparatus and journal articles;

(3) Knowledge (specific theories or skills);

(4) Organizations (universities, foundations, etc.);

(5) Occupations and disciplines;

(6) Institutions (established ways of thinking and doing among groups of people);

(7) Macroscopic institutions (industrial capitalism, for example); and

(8) Historical eras

Relationships between layers are multidirectional, and contingent rather than deterministic. For example, individual scientists are influenced by their disciplinary identities, and can sometimes push back to influence those disciplines. As an example of contingency, Akera points out that industrial capitalism (a 'macroscopic institution') undoubtedly influences organizations and knowledges in capitalist societies, but the

\footnotetext{
${ }^{4}$ Another use of the term 'ecology of knowledge' by Boaventura de Sousa Santos (2007) argues for recognizing a plurality of knowledges (coexisting in ecologies), challenging the dominance of Western rationality. While vitally important, this use of the term is distinct from Rosenberg's and therefore not dealt with in this article.

${ }^{5}$ We are grateful to two anonymous reviewers of this article for articulating, and pushing us to clarify, the distinction between these two uses of 'ecology.'
} 
specific nature of those influences cannot be predicted in advance and must be examined on a case-by-case basis (albeit with some common trends discernible).

We focus the framework on a single illustrative ecohealth research initiative to provide an exemplar within a specific context, and then widen to implications for the EkoSanté collaboration as a whole. The chosen illustrative initiative, 'the Puyango project', is a multi-year ecohealth action-research initiative on health effects of small-scale gold mining in the Puyango River basin in southwestern Ecuador. In populating the layers of the framework with entities drawn from our case study, we identify them using italics, and crossreference to the number of the layer in which we are placing them. For example, the end of the Cold War (8) is considered an historical era, while neoliberal ideology (7) is a macroscopic institution and medicine (5) is an occupation or discipline. Layer (8) (historical eras) covers the broadest geographical range, and layer 1 (actors) is the most 'local', in that the elements within it are uniquely combined in the Puyango project and nowhere else. The layers in between are more-or-less ordered by geographic scale, although this relationship may not hold in all cases (for example, the geographic range of an occupation, in layer (5), may not always be greater than that of an organization, on layer (4). A graphical summary of our case study is depicted in Figure 1. The elements that appear in layers 1-5 of Figure 1 are primarily drawn from published outputs of the Puyango project (Betancourt et al. 2005, 2012), supplemented by insider knowledge of the project lead, an EkoSanté member and co-author of this article. In populating layers 6-8, we also draw selectively from relevant ecohealth and social scientific scholarship, which in turn also unearths additional constituents of layers 1-5. Our assessment of which ecohealth and social scientific sources were relevant to the population of layers 6-8 was based on our collective experience conducting health-environment and social scientific research. Of methodological note, we depart slightly from Akera's treatment of Artifacts by including not only human-produced objects used in the generation of scientific knowledge, but also outputs of that research that exerted societal impacts (e.g. policy documents). In another departure from Akera's example, we also include non-human but nevertheless 'lively' Actors in Layer 1. These decisions are discussed in more detail following presentation of the case study.

We begin by foregrounding the origins of ecohealth as context for the Puyango project, and progress to consider specific project features in relation to ecohealth, neoliberalism and complex systems theories. We conclude this part by foregrounding the particular dynamics of mining and Canadian foreign policy in relation to the Puyango Project. 


\section{Layer 1 - Actors}

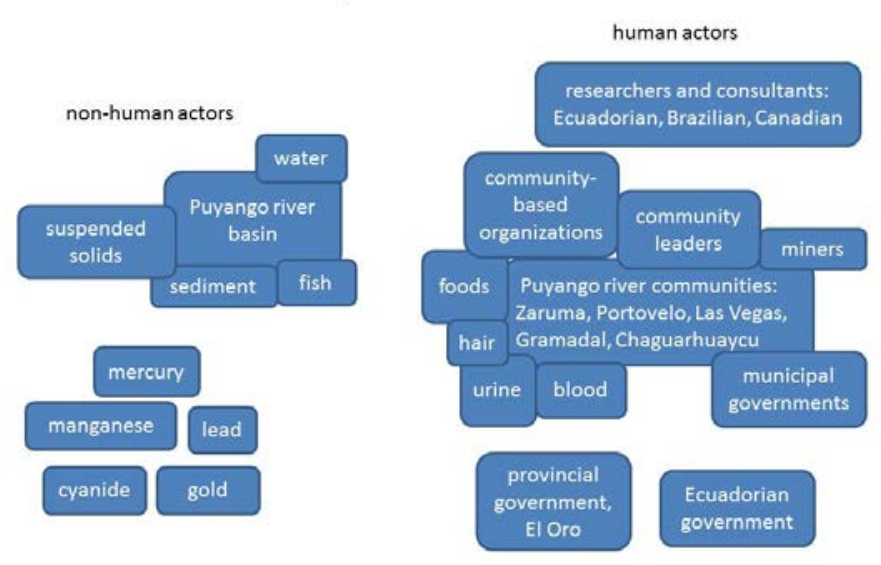

Layer 3 - Knowledges / Skills
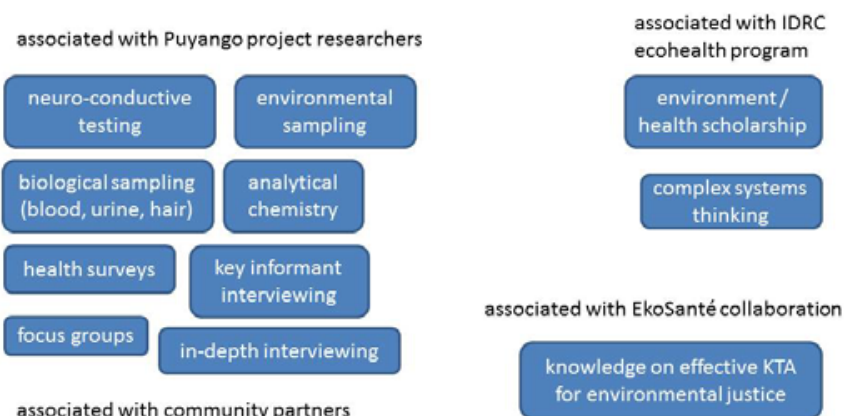

associated with community partners

Layer 2 - Artifacts

Used in the Puyango project

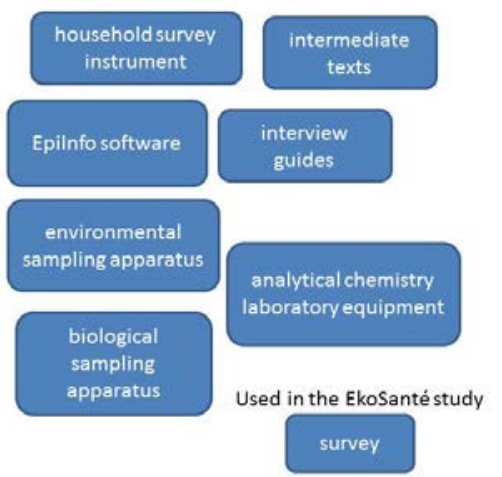

Issuing from the Puyango project

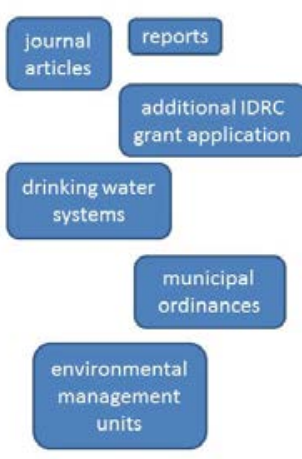

"local" knowledge

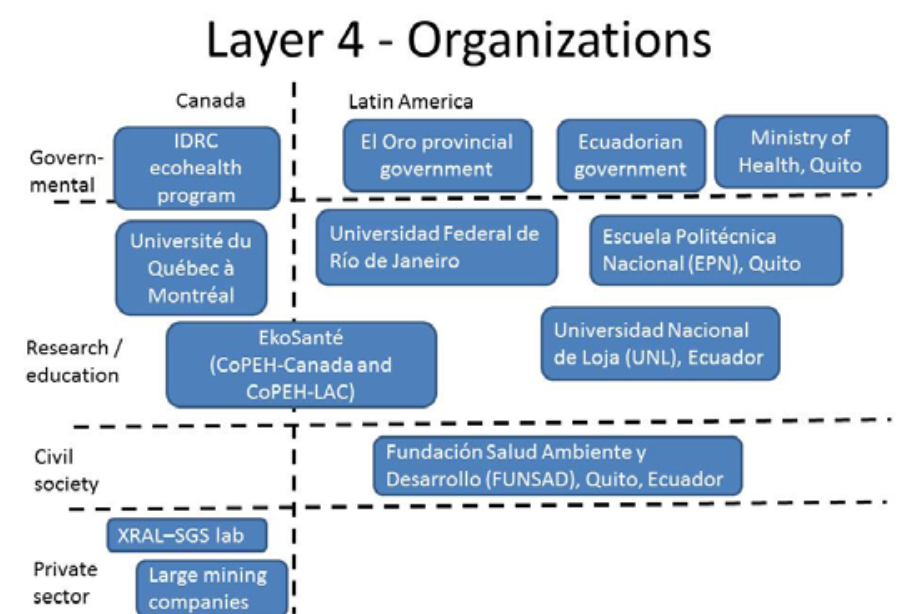

Figure 1: An ecology of ecohealth knowledge generation and application. Elements populating the diagram are drawn from the Puyango project outputs, the EkoSanté survey, and relevant social science literatures. Layers 1-5 represent an ecohealth project carried out in Ecuador's Puyango river basin, aimed at understanding and remedying health impacts of small-scale gold mining. Layers 6-8 largely apply more broadly to ecohealth research in the Americas, and especially the experiences of the EkoSanté collaboration. While elements are understood to interact within and across layers, these interactions are not depicted. 


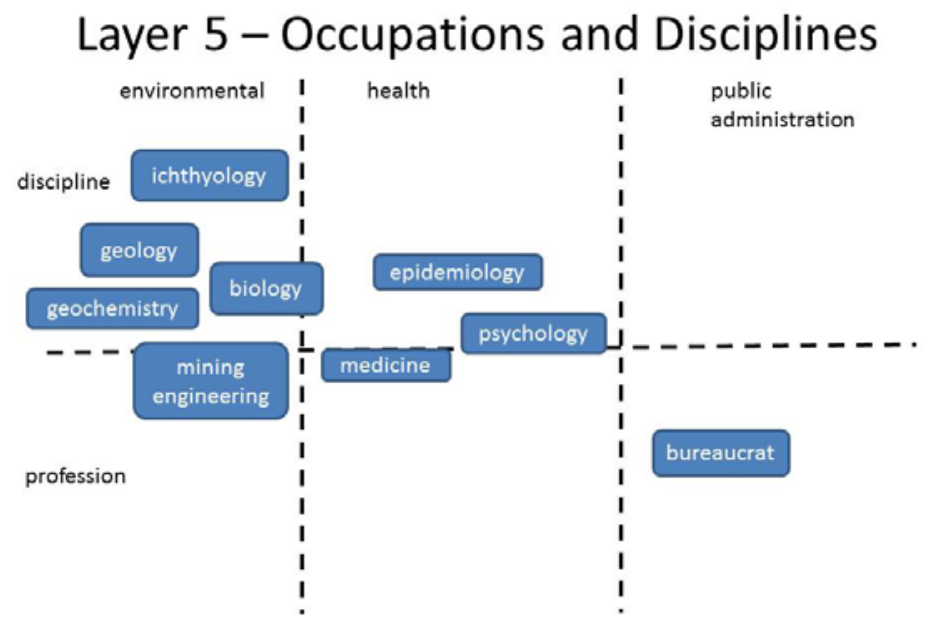

Layer 7 - Macroscopic institutions

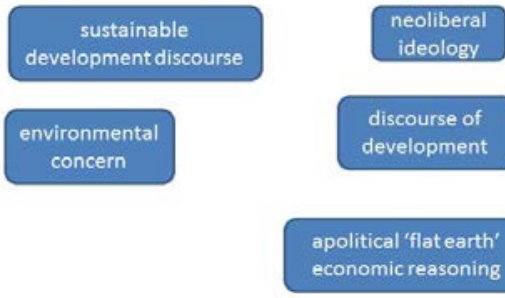

Figure 1 (continued).

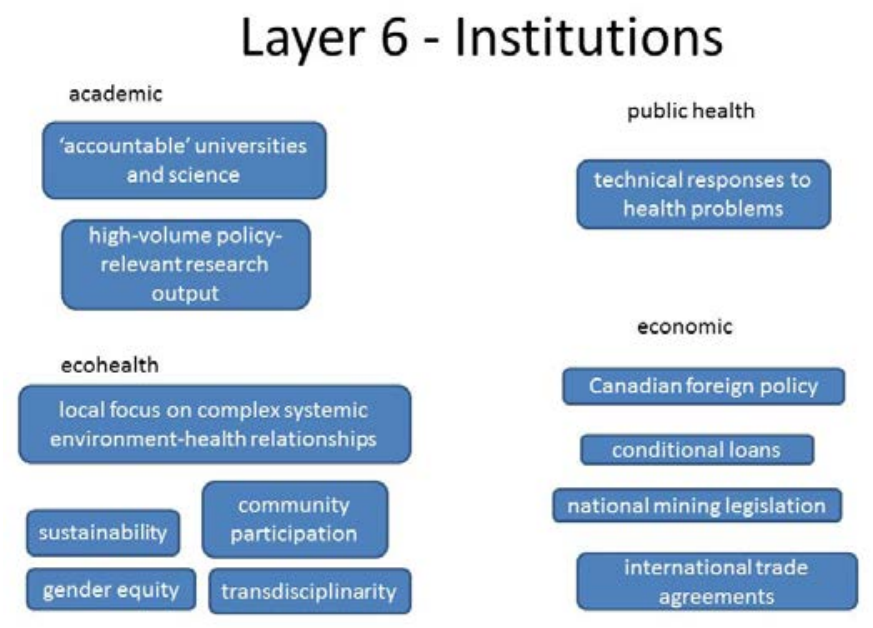

Layer 8- Historical events / eras

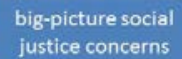

End of the Cold

War

Ecuadorian
financial crisis

Austerity era

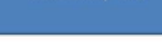

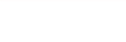




\section{Small-scale gold mining and health in Ecuador's Puyango River basin}

As described above, numerous ecohealth projects have been funded since the 1990s by Canada's IDRC (4), incorporating elements of transdisciplinarity (3), multi-stakeholder participation (3), attention to gender and other equity concerns (3), complex systems thinking (3), sustainability (3) and KTA (3) (Lebel 2003; Charron 2012). In the Puyango project, which took place from 1999-2007, Ecuadorian researchers (1) examined levels of toxic chemicals - lead, mercury, manganese and cyanide (1) - in the environment and in communities (1) living near gold mining activities in the Puyango River basin (1) in Ecuador's El Oro province. While the region was a major mining site for almost a century, the Ecuadorian financial crisis (8) of the late 1990s had led to the closure of large-scale mines, and a subsequent increase in small-scale mining. Partners in the study included community-based organizations and municipal leaders (1), as well as the El Oro provincial government (1) and the Ecuadorian national government (1). A survey of health conditions in participating communities was carried out with the help of local youth (1), who were trained in health survey methods as part of the project's capacity-building activities. The project also involved environmental sampling (3) of Puyango River water, sediment, fish (1), and food (1) consumed in communities downstream from goldmining activities.

Biological sampling (3) of blood, urine and hair (1) in these communities was also carried out. Samples were subsequently analyzed using a variety of analytical chemistry techniques (3) at laboratories in Quito's Ministry of Health (4), the Federal University of Rio de Janeiro (4), the Université du Québec à Montréal (4), and at a private laboratory in Toronto (4) (as not all appropriate laboratory facilities were available in Ecuador at the time). Additional skills and knowledges included health survey methods (3), neuro-conductive testing (3) of exposed community members for possible impairment caused by the environmental contaminants, as well as interviews and focus groups (3). The 'local' knowledges of community partners (3) also undoubtedly played a part in the project, consistent with ecohealth's transdisciplinary and participatory emphasis. For example, the study team was initially puzzled by high levels of lead in hair and blood samples from the lower region of the Puyango river watershed, an area with no obvious sources of lead such as automobile exhaust or leaded paint in houses. The team generated a hypothesis involving use of contaminated aluminum pots made in Peru, but questions to residents about use of aluminum pots were fruitless. Eventually, paying attention to the lived experience of local residents (3) revealed the presence of such pots, which were in fact thought by local residents to be made of iron, not aluminum.

Occupations and disciplines participating in the Puyango study included medicine / epidemiology, geology, geochemistry, mining engineering, psychology, environmental science, ichthyology, and bureaucrat / public service (5). The research employed Artifacts such as the software program EpiInfo (2) to determine appropriate sample sizes for the health survey; analytical chemistry apparatus (2) such as chromatographs and sample collection equipment; interview guides (2) and a survey instrument (2). Artifacts produced by the Puyango study included journal articles and reports (2), and - reflecting Latour's (1987) description of the role of texts in scientific knowledge production - intermediate texts (2) used in the course of the study but not appearing as published outputs. Complications related to Artifacts reveal complex ecologies of healthenvironment knowledge in a resource-constrained setting. For example, sites for environmental samples were chosen using both field visits and - due to resource constraints - existing maps (2). When the team arrived to take samples at some of the Puyango river sites chosen using maps, however, they found that the canyon walls were too steep to permit access to the river. On other occasions, the team's plan to collect environmental samples in both rainy and dry seasons was foiled by climatic irregularities (1), as particularly dry conditions prevented the taking of rainy-season samples and delayed the project (including with respect to its funderimposed deadlines). The use of computer-assisted neuro-behavioral test batteries (2) to detect neurotoxicity, developed in global North contexts, was also complicated by the lack of electricity (1) in certain regions of the Puyango basin. These physical realities - climatic variations and lack of electricity - thereby played a role as actors in the generation of knowledge, ultimately shaping how the research took place. Another related modification involve the necessity of purchasing glasses (2) that would allow some near-sighted residents who were unable to afford them to complete neuro-behavioral tests. Thus resource constraints, or a lack of appropriate Artifacts, played a major role in the construction of applied health-environment knowledge.

Finally, while ecology of knowledge studies have typically examined how social contexts influence scientific knowledge production, the converse (science's reciprocal impacts on its social context) can also be 
accommodated. With respect to the challenges of moving knowledge and evidence into policies, actions or practices, the Puyango project's Artifacts also included technologies and policy changes resulting from the action-research process: drinking water purification systems (2) in some riverine communities, as well as municipal ordinances (2) to prevent pollution and the establishment of Environmental Management Units (2) in two municipalities. Additional Artifacts issuing from the project included an additional IDRC grant application (2) to carry out further research (Betancourt et al. 2015; Guimaraes et al. 2011). These KTA outputs, moreover, were thoroughly shaped by the previously-described (unruly) social and material processes conditioning the project's generation of scientific knowledge.

\section{Ecohealth, neoliberalism and complex systems theories}

The specific distinction between (6) Institutions, (7) Macroscopic institutions and (8) Historical eras is not obvious, and so we complement the presentation of the layers depicted in Figure 1 with a brief historical discussion. This is consistent with the general observation that methods and data sources appropriate for analyzing one layer of the ecology of knowledge framework may not be appropriate for analyzing other layers, or interactions between layers. Importantly, many elements of layers 6-8 are not specific to the Puyango project but rather largely interchangeable among many of the IDRC ecohealth projects leading up to the EkoSanté collaboration. Cole, Crissman and Orozco (2006) describe the Ecohealth Program Initiative (4) as building on, and essentially replacing, IDRC's occupational health (5) activities, which were under threat in the early 1990s due to budget cuts. Environmental concern (7) concurrently growing internationally (as illustrated by the 1992 Rio Earth Summit) provided a context in which IDRC health programming could be maintained, albeit in a less politically-charged form than occupational health (5) with its typical labor movement alliances. Early IDRC health-environment projects, especially in Latin America, provided a core of expertise and promising case studies around which to build a new program in a difficult political climate. In designing the ecohealth program, the IDRC drew on scholarship on health-environment links (3) including environmental health and health-focused human ecology (c.f. Parkes, Panelli, and Weinstein 2003) to justify its focus on transdisciplinarity (6). An IDRC-produced article situates ecohealth in the history of Canadian thinking on population health and health promotion, with environmental factors becoming increasingly wellrecognized and informed by 'ecosystem approaches' to natural resource management (Forget and Lebel 2001).

While many portrayals of ecohealth celebrate its increasingly-sophisticated take on complex humanenvironment interactions, Cole et al. (2006) point out that the IDRC's incursion into ecohealth occurred during neoliberal reforms, such as structural adjustment programs in the global South, accompanying the end of the Cold War (8). According to Cole et al., big-picture social justice concerns (7) in health, such as those informing the 1978 Alma Ata Declaration, were subordinated in the ecohealth program to a local focus on complex systemic health-environment relationships (6), amenable to sophisticated scientific and social scientific analyses and environmental management responses. This focus reflects a strong engagement with complex systems and resilience theory (3) on the part of some ecohealth researchers (Hallström et al. 2015; Waltner-Toews and Kay 2005). Complex systems concepts informing different ecohealth researchers (and, indirectly, the IDRC ecohealth program; Charron 2012) include theories focused on managing human organizations, as well as currents in ecology challenging conventional views of ecosystems as progressing towards stable states (Bunch et al. 2008). Different schools of thought in complex systems and resilience theories illustrate important features of how social-ecological systems work (Turner 2014). One commonality among these schools of thought, however, is that they can be (and frequently are) applied in depoliticized ways that ignore power dynamics (Berbés-Blázquez et al. 2014; Hornborg 2013; McGreavy 2016). Walker and Cooper (2011), for example, point out how resilience thinking resonates with dominant manifestations of neoliberal ideology (7), such as the view that 'there is no alternative' to market-dominated economic globalization. As Nadasdy (2007) illustrates, furthermore, natural resource management for resilience is often carried out in ways that naturalize or legitimize colonial environmental dispossession of Indigenous peoples. Implications of this trend for ecohealth knowledge production are suggested by the observation that pressures for researchers to generate high volumes of policy-relevant research outputs in the neoliberal era of university accountability (6) limit time-consuming engagement with political economic inequities. One illustrative example is the dominance of depoliticized and neo-colonial depictions of Indigenous peoples in transdisciplinary community-engaged climate change research - a field with considerable similarities to, and 
even overlap with, ecohealth (Hall and Sanders 2015). Thus one hypothetical relationship between levels in the PEK framework involves the mutual interaction of complex systems theories (on level 3) with Institutions and Macroscopic institutions such as university accountability (6) and neoliberal ideology (7). Specifically, depoliticized application of complex systems theories allows for career advancement through rapid generation of 'relevant' research, within universities made 'accountable' in keeping with neoliberal ideology.

Consistent with this depoliticizing tendency is the production of a second IDRC book summarizing the ecohealth program (Charron 2012). The book's introduction includes critical Latin American social medicine or collective health approaches among the origins of ecohealth, and refers to "globalization" and "social and economic disparities between rich and poor around the world" (p. 3). Nevertheless, no reference is made to the economic policy decisions and factors responsible for phenomena such as globalization and wealth disparities. Consistent with the tendency described above for complex systems approaches to be applied in ways that naturalize neoliberal globalization, a "crisis in the world financial markets" is described as an "unpreventable" event (p. 15). This assumed inevitability implicitly naturalizes a phenomenon with demonstrable - and modifiable - social and political causes (cf. Harvey 2011). Scholars of international and global health, furthermore, have linked technical responses to health problems (6) in the global South with apolitical, "flat earth" political economic reasoning (7) that hides histories of colonialism and presents poverty as a kind of inexplicable or geographic accident (Sparke 2009). While some ecohealth researchers might protest that ecohealth's complexity-attuned focus is in fact the opposite of a "technical response" to health problems, many (though not all) ecohealth projects can be considered technical in that they target health problems related to political inequities using techniques of (environmental) management, without addressing the larger-scale driving forces of those inequities. Similarly, technical responses to healthenvironment problems such as malaria (Packard 1997) and pesticide exposure (Brisbois 2014) have been shown to resonate strongly with what Escobar (1995) terms the discourse of development (7): namely, the portrayal of places in the global South as requiring technical intervention in the form of international development programming, in ways that ultimately leave inequitable North-South political and economic power relations untouched. Consistent with this trend, a 2003 IDRC book describes the "promise" of ecohealth research for development. The book asks "Can people remain healthy in a world that is sick?" (Lebel 2003: 1), but presents small-scale ecohealth projects in which individual communities engage with local environmental degradation, and not with the political economic power relations driving global environmental and social change on the 'world' stage.

\section{Mining, ecohealth and Canadian foreign policy}

The multi-layered ecology of knowledge framework thus provides a number of entry points for examining interactions between political economy and the production, application and circulation of healthenvironment knowledge. A notable illustration of this is provided by several ecohealth projects, focused on small-scale artisanal gold mining, which were funded by the IDRC (such as the Puyango study described above) but which largely avoided the impacts of large-scale mining. Tellingly, at the same time that Canada's foreign policy (6) was supporting the IDRC ecohealth program, it was also contributing to re-writing of national mining legislation in places such as Guyana, Honduras and Colombia (Black and McKenna 1995; Blackwood and Stewart 2012; Gordon and Webber 2014). This re-writing facilitated the entry into these countries of Canadian companies - companies that have been accused of numerous human rights and environmental violations (Bebbington and Bury 2013; Deneault et al. 2008; North and Young 2013). Access to mineral resources in the global South for large mining companies (4) - of which fully $75 \%$ raise funds on Canadian stock exchanges - has been promoted through mechanisms of neoliberalization such as conditional loans (6) requiring liberalization of national economies, international trade agreements (6), and national mining legislation (6) facilitating foreign investment (Butler 2015; Coumans 2010; Deneault and Sacher 2012; Kirsch 2014). The aggressive search for mineral resources that has led Canadian mining companies to Latin America was therefore made possible by the same neoliberal economic policies and ideology surrounding the origins of the IDRC ecohealth program (cf. Gordon 2010). The implications of the ecohealth program's focus on small-scale mining, while the Canadian government systematically promoted large-scale mining around the world, are further illustrated by Moore and Velásquez's (2012) examination of small and large-scale mining in Ecuador's Azuay province (adjacent to the province where the Puyango project took 
place). They show how the Ecuadorian government made rhetorical use of the environmental damages caused by small-scale gold miners to portray large-scale - often Canadian - mine developments as environmentally responsible, simultaneously cracking down on civil society and Indigenous groups opposing large-scale mines. This finding is echoed by Butler (2015) with respect to Tanzania, where portrayals of small-scale miners as unskilled, lawless and environmentally destructive were used by Canadian mining personnel to justify the eviction of small-scale miners from the sites of future large-scale mines. Thus focusing negative attention on small-scale miners has repeatedly emerged as a political strategy for the promotion of large-scale mining.

A particularly aggressive form of mining-focused Canadian foreign policy began when the Conservative government came to power in 2006, in what we are terming the austerity era (8). This era saw increasing use of Canadian development funds to mitigate negative social and environmental impacts of large-scale mining - essentially using public funds to finance corporate social responsibility (CSR) activities of highly-profitable companies (Bodruzic 2015). CSR efforts by the mining industry (6) obtain social legitimation of mining company practices. CSR, when specifically targeted at universities and researchers can buy supportive scientists, and generate the 'symbolic capital' required to avoid regulation or loss of access to mineral resources (Brisbois et al. 2016; Coumans 2010; Kirsch 2014). Significantly, the Conservative government added an executive from Barrick Gold, and leader of the Mining Association of Canada's international CSR committee, to the IDRC's Board of Governors (Shane 2015). Barrick Gold at the time was the world's largest gold mining company and likely its most controversial (Coumans 2011; Deneault et al. 2008; Jeppesen and Nazar 2012; Tannock 2010). The appointment exemplifies the Canadian government's attempts to legitimize large-scale mining around the world, in this case using the reputation of a highlyrespected Crown Corporation.

To spell out the ecology of knowledge implications of this situation, the IDRC's funding of research on small-scale mining did not challenge and may even have deflected attention away from large-scale mining, consistent with its main funder's support for Canada's large mining sector (the Canadian government). The role of the extractive sector in influencing both the Ecuadorian policy space within which ecohealth science could be applied, and research priorities at ecohealth's main funder (the IDRC), neatly encapsulates the limitations of KTA and other evidence-based approaches when they are applied without explicit attention to political and economic power.

\section{Limitations and avenues for future research}

The preceding analysis illustrates how power-conscious attention to the social construction and application of health-environment knowledge uncovers contradictions and inequities built into much applied health-environment research. In so doing, it opens up avenues for further study, but also for simultaneous advocacy on the part of health-environment scientists, political ecologists, and - ideally - alliances of the two groups. In considering such future work, however, we recognize that our application of the ecology of knowledge framework displays some limitations. The example depicted in Figure 1, for example, depicts Knowledges involved in a particular research program on the same layer as Knowledges informing the IDRC ecohealth program funding the research and - through grant application processes and reporting requirements - affecting how the research takes place. The specific nature of this interaction would require detailed empirical work to document, although health researchers and funding organization staff personally navigating such interactions could no doubt fill in many of the details. In our experience, for example, the critical explorations informing this article are not actively promoted by the IDRC, but are nevertheless enabled by the freedom that IDRC staff such as regional program officers extend to funded researchers and students.

As Akera (2007) notes, the elements that could be included in an ecology of knowledge representation are essentially infinite, but the number that can be meaningfully held in focus at one time is inevitably finite. Figure 1 and its accompanying narrative are intended to illustrate the possible uses of the framework, but we recognize that they do not represent a definitive or exhaustive portrayal of the Puyango project or ecohealth research more generally. We largely confined ourselves to representing layers and their constituents, and engaged in relatively little exploration of relationships among and within layers. Such exploration, which we suggest will ultimately be necessary to make best use of the framework, could draw on understandings that health-environment scientists and researchers have of their own political ecologies of knowledge (cf. Taylor 
1990). For example (and returning to the task of populating Figure 1), the EkoSanté survey (2), which took place at the end of the IDRC's programmatic emphasis on ecohealth research, summarizes experiences of attempting - successfully or otherwise - to apply ecohealth knowledge, potentially allowing for development of new knowledge on effective KTA for environmental justice (3) and, with time, changes to related KTA practices (6).

STS scholarship on the co-production of science and social order (Jasanoff 2004) would be invaluable in supporting such processes, as would the actual participation of STS scholars - likely ones working in an 'engaged program' that explicitly seeks to promote better, more equitable models of science-society interaction (Sismondo 2008). Postcolonial research on how health science 'travels' in North-South interaction (Anderson 2014; Brisbois 2014; Crane 2013; Pigg 2001) could also provide theoretical and methodological guidance for examining interactions such as Canada-Latin America ecohealth collaborations. For example, the complicated journey to the Puyango basin of neuro-behavioral tests developed in global North settings, where electricity and prescription glasses are readily available, hints at some of the dynamics of such travels. Ecologies of health-environment knowledge in the context of academic internationalization can therefore advance understanding of the circulation of scientific knowledge and North-South asymmetries and inequities in scientific production.

\section{Towards political ecologies of applied health-environment knowledge}

Taking into account the above limitations, our analysis suggests some of the possibilities of an explicit focus on political ecologies of applied health-environment knowledge, ${ }^{6}$ foregrounding the influence of power dynamics - political economic, gendered or related to race and ethnicity - on the generation and application of knowledge. Sundberg and Dempsey (2014, p. 175) describe political ecology as "a political stance toward the world and, therefore, research", making it especially appropriate for politicizing STS approaches. Political ecology's well-developed focus on issues of power in relation to environmental change provides a helpful reminder - consistent with public health's increasing focus on 'equity' - that persistently unfair power structures continue to shape the distribution of environmental and health harms (Martinez-Alier et al. 2014), as well as the processes by which knowledge of those harms is generated and applied (Goldman et al. 2011). Our purpose is not to suggest that previous ecology of knowledge analyses have been blind to power, but instead that political ecology can add a critical and applied edge to their perceptive approaches. Political ecologists, furthermore, have worked across an impressive range of diverse contexts, paying close attention to the interaction of ecosystem dynamics and distinct explanatory discourses based in scientific disciplines, and among scientists, professionals and communities around the world.

We also provisionally included non-human entities - sediment, mercury, fish, blood, hair, a river, etc. - as Actors in our case study. The specific role or agency of such actors - both more-than-human and withinhuman-body - in environmental change and related research is a central object of study among political ecologists (Collard et al. 2015; Guthman and Mansfield 2013; cf. Latour 2005). We enthusiastically recommend analyses that look at the role of such 'lively' actors within knowledge generation on health and the environment and its application. This point returns us to the distinction alluded to earlier, between ecology as metaphor for the interacting social factors involved in scientific knowledge generation, and ecology as a source of empirical insights about the natural world. Both political ecology and health-environment fields such as ecohealth will no doubt continue to treat ecology as a discipline of study, and source of scientific data about actual ecosystems. One possibility is that ecosystem metaphors be thought of as capturing the complex systemic and multi-scale dynamics of social and ecological influences on (and of) health-environment science (cf. Best and Holmes 2010). We believe that political ecologies of knowledge can simultaneously, and in a power-conscious way, capture both of these complex systemic dynamics. ${ }^{7}$ More explicit attention to the roles of ecosystems and their inhabitants in health, health research, and attempts to use such research can provide

\footnotetext{
${ }^{6}$ One previous use of the term 'political ecology of knowledge' is Scandrett's (2012) exploration of social learning in environmental justice struggles, which does not reference ecology of knowledge frameworks in STS.

${ }^{7}$ A third interpretation revisits ecology as the study (-logy) of our home: informed by the Latin origins of eco- as oikos (household, home), and encouraging a view of ecosystems as living systems, that encompass social and ecological settings for health and well-being (Parkes and Horwitz 2016).
} 
valuable support to struggles for environmental justice (Jackson and Neely 2015; Martinez-Alier et al. 2014; Parkes et al. 2003).

\section{Conclusion: KTA, political ecology and engaged scholarship}

Our analysis illustrates how a political ecological focus incorporating insights from STS, applied to knowledge-to-action and other evidence-based health approaches, generates findings with major implications for understanding the simultaneous production of health-environment knowledge and environmental injustice. For example, the absence of certain large-scale political economic considerations in official IDRC ecohealth discourse appears to be an enabling condition (though a problematic one) in the field's ecology of knowledge. The absence of attention to such political economic dynamics can enable international development research to occur through politically-uncontroversial application of specific technical approaches, now incorporating complex systems theories and sophisticated knowledge of health-ecosystem interactions. In fact, one compelling interpretation of the results in this article could use Thomas Kuhn's (1962) description of a paradigm, or set of assumptions enabling "normal science" to occur rapidly without researchers having to repeatedly re-establish the foundations of their discipline or field. Lack of attention to large-scale political and economic power appears to represent a paradigmatic assumption of much early ecohealth research (though of course with resistance and creative challenges from many ecohealth researchers), one that was consistent with the ideological stance of the Canadian government funding much ecohealth activity.

In this light, a major factor limiting the effectiveness of KTA efforts - political and economic power as manifested by corporate actors, their governmental allies and the ideologies they promote - can also be implicated in how new fields of study are formed and funded. This observation complements STS work addressing 'neoliberal science' (Lave, Mirowski, and Randalls 2010) by illustrating the interaction between complex-systemic ecosystem management approaches to health, and Canada's arguably neoliberal foreign policy interventions. Specifically, policies consistent with neoliberal ideology appear to motivate or justify the institutionalization of accountability mechanisms within universities, which in turn incentivize particular kinds of scholarship - including complex systems approaches that are often unencumbered by excessive attention to historical and ongoing inequities. Such realizations motivate our strong recommendation that health-environment scientists pay more attention to such political and economic power relationships not only as objects of research, but also as part of the reflexivity involved in considering the context of their research, its application, and the limitations in both. As illustrated by the nuanced perspectives on KTA voiced by many EkoSanté survey participants, thoughtful health-environment researchers are already concerned with relationships between science and society and related equity issues. We hope that this article provides a useful set of tools to deepen such exploration.

Returning to the engaged aspirations we outlined in the introduction to this article, our (political) ecology of knowledge analysis suggests some avenues for future applied scholarship or advocacy. In particular, we argue that the huge and influential currents of health research and practice focused on moving from knowledge to action represent an important area of engagement for political ecologies of health aimed at actual societal impact. Community-based ecohealth projects represent one potential entry point for such engagement, but local-scale health-environment research projects are not sufficient in light of the thoroughly globalized nature of health inequities. There is a related imperative to also account for macroeconomic and political economic influences on health and on knowledge production, exemplified in our case study by Canada's mining industry. Radical or Freirean approaches are among the most power-conscious participatory techniques, and their focus on linked reflection and action in struggles for liberation - praxis - is highly relevant to the project of engaged or applied scholarship (Freire 2004). Such empowerment-based strategies have been previously highlighted by political ecologists as appropriate responses to inequitable healthenvironment issues, although behavior-change public health approaches represent persistent obstacles to emancipatory political change (Galt 2013). The interaction between community participation and behaviorchange objectives in the EkoSante survey results discussed above shows that ecohealth researchers are confronting such tensions in ways that could be enhanced by engagement with political ecology. Such engagement would draw on political ecologists' conventional strengths in analyzing power, environmental change and narratives, as well as their emerging expertise in understanding the social production and application of health-environment knowledge. 
Environment and health researchers, however, may find themselves uncomfortable with some of the claims made in this article, as well as the kinds of 'evidence' upon which they are based. For example, influences of the discourse of development (Escobar 1995) (a Macroscopic institution in Figure 1) on healthenvironment scholarship do not fit easily into epidemiological or other environment and health hierarchies of evidence. Nevertheless, stories such as the one told in this article are routinely told by environment and health scientists, if only to themselves (Taylor 2011). That is, all environment and health researchers already make sense of the array of factors influencing their work, their ability to continue doing it, and its ultimate impact on the world. With the exception of scholarship on KTA, however, most of this sense-making is based on personal experience, values, mentorship relationships, shared disciplinary assumptions, etc. - in short, based on anything but empirically- and theoretically-sound scholarship. Political ecology of knowledge approaches may therefore help researchers and practitioners make better sense of the complex world in which they must make a living, and ideally make a difference.

\section{References}

Adams, V. 2013. Evidence-based global public health: subjects, profits, erasures. In Biehl, J. and A. Petryna (eds.) When people come first: critical studies in global health. Princeton, NJ: Princeton University Press. Pp. 54-90.

Akera, A. 2007. Constructing a representation for an ecology of knowledge: methodological advances in the integration of knowledge and its various contexts. Social Studies of Science 37(3): 413-441.

Anderson, W. 2014. Making global health history: the postcolonial worldliness of biomedicine. Social History of Medicine 27(2): 372-384.

Bebbington, A. and J. Bury. 2013. Political ecologies of the subsoil. In Bebbington, A. and J. Bury (eds.) Subterranean struggles: new dynamics of mining, oil, and gas in Latin America. Austin: University of Texas Press. Pp. 1-25.

Behague, D., C. Tawiah, M. Rosato, T. Some and J. Morrison. 2009. Evidence-based policy-making: the implications of globally-applicable research for context-specific problem-solving in developing countries. Social Science and Medicine 69(10): 1539-1546.

Berbés-Blázquez, M., J.S. Oestreicher, F. Mertens and J. Saint-Charles. 2014. Ecohealth and resilience thinking: a dialog from experiences in research and practice. Ecology and Society 19(2): 24.

Best, A. and B. Holmes. 2010. Systems thinking, knowledge and action: towards better models and methods. Evidence and Policy 6(2): 145-159.

Betancourt, Ó., R. Barriga, J.R.D. Guimarães, E. Cueva and S. Betancourt. 2012. Impacts on environmental health of small-scale gold mining in Ecuador. In Charron, D. (ed.) Ecohealth research in practice. Ottawa: Springer and International Development Research Centre. Pp. 119-130.

Betancourt, Ó., A. Narváez and M. Roulet. 2005. Small-scale gold mining in the Puyango River basin, southern Ecuador: a study of environmental impacts and human exposures. EcoHealth 2(4): 323-332.

Betancourt, Ó., M. Tapia and I. Méndez. 2015. Decline of general intelligence in children exposed to manganese from mining contamination in Puyango River basin, southern Ecuador. EcoHealth 12(3): 453-460.

Birch, K. 2013. The political economy of technoscience: an emerging research agenda. Spontaneous Generations 7: 49-61.

Black, D.R. and P. McKenna. 1995. Canada and structural adjustment in the south: the significance of the Guyana case. Canadian Journal of Development Studies 16(1): 55-78.

Blackwood, E. and V. Stewart. 2012. CIDA and the mining sector: extractive industries as an overseas development strategy. In Brown, S. (ed.) Struggling for effectiveness: CIDA and Canadian foreign aid. Montreal and Kingston: McGill-Queen's University Press. Pp. 217-245.

Blaikie, P. 2012. Should some political ecology be useful? The inaugural lecture for the cultural and political ecology specialty group. Geoforum 43: 231-239. 
Bodruzic, D. 2015. Promoting international development through corporate social responsibility: the Canadian government's partnership with Canadian mining companies. Canadian Foreign Policy Journal 21(2): 129-145.

Bonet, M., J.M. Spiegel, A.M. Ibarra, G. Kouri, A. Pintre and A. Yassi. 2007. An integrated ecosystem approach for sustainable prevention and control of dengue in Central Havana. International Journal of Occupational and Environmental Health 13(2): 188-194.

Bowen, S.J. and I.D. Graham. 2013. From knowledge translation to engaged scholarship: promoting research relevance and utilization. Archives of Physical Medicine and Rehabilitation 94(1): S3-S8.

Breilh, J. 2012. Coping with environmental and health impacts in a floricultural region of Ecuador. In Charron, D.F. (ed.) Ecohealth research in practice. Ottawa, ON: Springer and International Development Research Centre. Pp. 59-68.

Brisbois, B.W. 2014. Epidemiology and 'developing countries': writing pesticides, poverty and political engagement in Latin America. Social Studies of Science 44(4): 600-624.

Brisbois, B.W. 2016. Bananas, pesticides and health in southwestern Ecuador: a scalar narrative approach to targeting public health responses. Social Science and Medicine 150: 184-191.

Brisbois, B.W., D.C. Cole, C.M Davison, E. Di Ruggiero, L. Hanson, C.R. Janes, C. Larson, S. Nixon, K. Plamondon and B. Stime. 2016. Corporate sponsorship of global health research: Questions to promote critical thinking about potential funding relationships. Canadian Journal of Public Health 107(4-5): e390-e392.

Bunch, M., D. McCarthy and D. Waltner-Toews. 2008. A family of origin for an ecosystem approach to managing for sustainability. In Waltner-Toews, D., J. Kay, and N.-M. Lister (eds.) The ecosystem approach: complexity, uncertainty, and managing for sustainability. New York: Columbia University Press. Pp. 125-138.

Butler, P. 2015. Colonial extractions: race and Canadian mining in contemporary Africa. Toronto: University of Toronto Press.

Charron, D.F. (ed.) 2012. Ecohealth research in practice. Ottawa: Springer and International Development Research Centre.

Cole, D.C., C.C. Crissman and A.F. Orozco. 2006. Canada's International Development Research Centre's eco-health projects with Latin Americans: origins, development and challenges. Canadian Journal of Public Health 97(6): I8-I14.

Collard, R.-C., J. Dempsey and J. Sundberg. 2015. A manifesto for abundant futures. Annals of the Association of American Geographers 105(2): 322-330. Academia

Connolly, C., P. Kotsila and G. D'Alisa. 2017. Tracing narratives and perceptions in the political ecologies of health and disease. Journal of Political Ecology 24: 1-10.

Coumans, C. 2010. Alternative accountability mechanisms and mining: the problems of effective impunity, human rights, and agency. Canadian Journal of Development Studies 30(1-2): 27-48.

Coumans, C. 2011. Occupying spaces created by conflict: anthropologists, development NGOs, responsible investment, and mining. Current Anthropology 52(S3): S29-S43.

Crane, J.T. 2013. Scrambling for Africa: AIDS, expertise, and the rise of American global health science. Ithaca NY: Cornell University Press.

Dakubo, C.Y. 2011. Ecosystems and human health: a critical approach to Ecohealth research and practice. New York: Springer.

Davison, C.M., S. Ndumbe-Eyoh and C. Clement. 2015. Critical examination of knowledge to action models and implications for promoting health equity. International Journal for Equity in Health 14(1): 49.

de Leeuw, E., A. McNess, B. Crisp and K. Stagnitti. 2008. Theoretical reflections on the nexus between research, policy and practice. Critical Public Health 18(1): 5-20.

Deneault, A., D. Abadie and W. Sacher. 2008. Noir Canada: pillage, corruption et criminalité en Afrique. Montréal: Ecosociété.

Deneault, A. and W. Sacher. 2012. Imperial Canada Inc.: legal haven of choice for the world's mining industries. Vancouver: Talonbooks. 
Denny, K. 1999. Evidence-based medicine and medical authority. Journal of Medical Humanities 20: 247263.

de Sousa Santos, B. 2007. Beyond abyssal thinking: from global lines to ecologies of knowledges. Review (Fernand Braudel Center) 30: 45-89.

Escobar, A. 1995. Encountering development: the making and unmaking of the third world. Princeton, NJ: Princeton University Press.

Forget, G. and J. Lebel. 2001. An ecosystem approach to human health. International Journal of Occupational and Environmental Health 7(2 Suppl): S3-38.

Freire, P. 2004. Pedagogy of the oppressed. New York: Continuum.

Galt, R. 2011. Circulating science, incompletely regulating commodities: governing from a distance in transnational agro-food networks. In Goldman, M., P. Nadasdy and M. Turner (eds.) Knowing nature: conversations at the intersection of political ecology and science studies. Chicago: University of Chicago Press. Pp. 227-243.

Galt, R.E. 2013. From homo economicus to complex subjectivities: reconceptualizing farmers as pesticide users. Antipode 45(2): 336-356.

Goldman, M.J., P. Nadasdy and M.D. Turner (eds.) 2011. Knowing nature: conversations at the intersection of political ecology and science studies. Chicago: University of Chicago Press.

Goldman, M.J., and M.D. Turner. 2011. Introduction. In Goldman, M.J., P. Nadasdy and M.D. Turner (eds.) Knowing nature: conversations at the intersection of political ecology and science studies. Chicago: University of Chicago Press. Pp. 1-24.

Gordon, T. 2010. Imperialist Canada. Winnipeg: Arbeiter Ring Publications.

Gordon, T. and J.R. Webber. 2014. Canadian geopolitics in post-coup Honduras. Critical Sociology 40(4): 601-620.

Greenhalgh, T., G. Robert, F. Macfarlane, P. Bate, O. Kyriakidou and R. Peacock. 2005. Storylines of research in diffusion of innovation: a meta-narrative approach to systematic review. Social Science and Medicine 61(2): 417-430. Academia

Greenhalgh, T. and J. Russell. 2009. Evidence-based policymaking: a critique. Perspectives in Biology and Medicine 52(2): 304-318.

Guimaraes, J.R.D., O. Betancourt, M.R. Miranda, R. Barriga, E. Cueva and S. Betancourt. 2011. Long-range effect of cyanide on mercury methylation in a gold mining area in southern Ecuador. Science of the Total Environment 409(23): 5026-5033.

Guimarães, J.R.D. and D. Mergler. 2012. A virtuous cycle in the Amazon: reducing mercury exposure from fish consumption requires sustainable agriculture. In Charron, D.F. (ed.) Ecohealth research in practice. Ottawa: Springer and International Development Research Centre. Pp. 109-118.

Guthman, J. and B. Mansfield. 2013. The implications of environmental epigenetics: a new direction for geographic inquiry on health, space, and nature-society relations. Progress in Human Geography 37(4): 486-504.

Hackett, E.J., O. Amsterdamska, M. Lynch and J. Wajcman (eds.) 2008. The handbook of science and technology studies. Cambridge: MIT Press.

Hall, E.F. and T. Sanders. 2015. Accountability and the academy: producing knowledge about the human dimensions of climate change. Journal of the Royal Anthropological Institute 21(2): 438-461.

Hallström, L.K., M.W. Parkes and N.P. Guehlstorf. 2015. Convergence and diversity: Integrating encounters with health, ecological and social concerns. In Hallström, L.K., N.P. Guehlstorf and M.W. Parkes (eds.) Ecosystems, society, and health: pathways through diversity, convergence, and integration. Montreal: McGill-Queen's University Press. Pp. 3-32.

Harvey, D. 2011. The enigma of capital and the crises of capitalism. London: Profile Books.

Holmes, D., S.J. Murray, A. Perron and G. Rail. 2006. Deconstructing the evidence-based discourse in health sciences: truth, power and fascism. International Journal of Evidence-Based Healthcare 4: 180-186.

Hornborg, A. 2013. Revelations of resilience: from the ideological disarmament of disaster to the revolutionary implications of (p)anarchy. Resilience 1(2): 116-129. 
Jackson, P. and A.H. Neely. 2015. Triangulating health: toward a practice of a political ecology of health. Progress in Human Geography 39(1): 47-64. Academia

Jasanoff, S. (ed.) 2004. States of knowledge: the co-production of science and social order. New York: Routledge.

Jeppesen, S. and H. Nazar. 2012. Beyond academic freedom: Canadian neoliberal universities in the global context. TOPIA: Canadian Journal of Cultural Studies 1(28): 87-113.

King, B. 2015. Political ecologies of disease and health. In Perreault, T., G. Bridge and J. McCarthy (eds.) The Routledge handbook of political ecology. London: Routledge. Pp. 343-353.

Kirsch, S. 2014. Mining capitalism: the relationship between corporations and their critics. Oakland, CA: University of California Press.

Kuhn, T.S. 1962. The structure of scientific revolutions. Chicago: University of Chicago Press.

Labonte, R., M. Polanyi, N. Muhajarine, M. McIntosh and A. Williams. 2005. Beyond the divides: towards critical population health research. Critical Public Health 15(1): 5-17.

Latour, B. 1987. Science in action: how to follow scientists and engineers through society. Cambridge: Harvard University Press. Intro

Latour, B. 2005. Reassembling the social: an introduction to actor-network-theory. Oxford: Oxford University Press.

Lave, R., P. Mirowski and S. Randalls. 2010. Introduction: STS and neoliberal science. Social Studies of Science 40(5): 659-675.

Lave, R. 2012. Neoliberalism and the production of environmental knowledge. Environment and Society 3: 19-38. Academia

Martinez-Alier, J., I. Anguelovski, P. Bond, D. Del Bene, F. Demaria, J.F. Gerber, L. Greyl, W. Haas, H. Healy, M. Marín-Burgos, G. Ojo, M.F. Porto, L. Rijnhout, B. Rodríguez-Labajos, J. Spangenberg, L. Temper, R. Warlenius, I. Yánez. 2014. Between activism and science: grassroots concepts for sustainability coined by EJOs. Journal of Political Ecology 21: 19-60.

McGreavy, B. 2016. Resilience as discourse. Environmental Communication 10(1): 104-121.

McInnes, C. and K. Lee. 2012. Framing and global health governance: key findings. Global Public Health 7(sup2): S191-S198.

McSweeney, K. and Z. Pearson. 2013. Vaccines, fertility, and power: the political ecology of indigenous health and well-being in lowland Latin America. In King, B. and K.A. Crews (eds.) Ecologies and politics of health. New York: Routledge. Pp. 139-158.

Moore, J. and T. Velásquez. 2012. Water for gold: Confronting state and corporate mining discourses in Azuay, Ecuador. In Bebbington, A. and J. Bury (eds.) Subterranean struggles: new geographies of extractive industries in Latin America. Austin: University of Texas Press. Pp. 119-148.

Mykhalovskiy, E., P. Armstrong, H. Armstrong, I. Bourgeault, J. Choiniere, J. Lexchin, S Peters and J. White.. 2008. Qualitative research and the politics of knowledge in an age of evidence: developing a research-based practice of immanent critique. Social Science and Medicine 67(1): 195-203.

Mykhalovskiy, E. and L. Weir. 2004. The problem of evidence-based medicine: directions for social science. Social Science and Medicine 59(5): 1059-1069.

Nadasdy, P. 2007. Adaptive co-management and the gospel of resilience. In Armitage, D., F. Berkes and N.C. Doubleday (eds.) Adaptive co-management: collaboration, learning and multi-level governance. Vancouver, BC: UBC Press. Pp. 208-227.

Neely, A.H. 2015. Internal ecologies and the limits of local biologies: a political ecology of tuberculosis in the time of AIDS. Annals of the Association of American Geographers 105(4): 791-805.

North, L.L. and L. Young. 2013. Generating rights for communities harmed by mining: legal and other action. Canadian Journal of Development Studies 34(1): 96-110.

Orozco, F.A. and D.C. Cole. 2012. Tackling challenges to farmers' health and agro-ecosystem sustainability in highland Ecuador. In Charron, D.F. (ed.) Ecohealth research in practice. Ottawa: International Development Research Centre and Springer. Pp. 47-58. 
Packard, R.M. 1997. Malaria dreams: postwar visions of health and development in the Third World. Medical Anthropology 17(3): 279-296.

Parkes, M., R. Panelli and P. Weinstein. 2003. Converging paradigms for environmental health theory and practice. Environmental Health Perspectives 111(5): 669-675.

Parkes, M.W., D.F. Charron and A. Sanchez. 2012. Better together: field-building networks at the frontiers of ecohealth research. In Charron, D.F. (ed.) Ecohealth research in practice. Ottawa: Springer and International Development Research Centre. Pp. 231-254.

Parkes, M.W. and P. Horwitz. 2016. Ecology and ecosystems as foundational for health. In Frumkin, H. (ed.) Environmental health: from global to local (3rd ed.). San Francisco: Jossey-Bass. Pp. 27-58.

Pigg, S.L. 2001. Languages of sex and AIDS in Nepal: notes on the social production of commensurability. Cultural Anthropology 16: 481-541.

Pope, C. 2003. Resisting evidence: the study of evidence-based medicine as a contemporary social movement. Health 7: 267-282.

Ráez-Luna, E. 2008. Third world inequity, critical political economy, and the ecosystem approach. In Waltner-Toews, D., J. Kay and N.-M. Lister (eds.) The ecosystem approach: complexity, uncertainty, and managing for sustainability. New York: Columbia University Press. Pp. 323-333.

Robbins, P. 2012. Political ecology: a critical introduction (2nd ed.). Malden: Wiley.

Rocheleau, D.E. 2008. Political ecology in the key of policy: from chains of explanation to webs of relation. Geoforum 39(2): 716-727. Academia

Rosenberg, C. 1979. Toward an ecology of knowledge: on discipline, context, and history. In Oleson A. and J. Voss (eds.) The organization of knowledge in modern America, 1860-1920. Baltimore: Johns Hopkins University Press. Pp. 440-455.

Rosenberg, C.E. 1988. Editorial: woods or trees? Ideas and actors in the history of science. Isis 79(4): 564570.

Scandrett, E. 2012. Social learning in environmental justice struggles: a political ecology of knowledge. In Hall, B.L., D.E. Clover, J. Crowther and E. Scandrett (eds.) Learning and education for a bettter world. Rotterdam: Sense Publishers. Pp. 41-56.

Shane, K. 2015. Barrick exec with Tory ties appointed to IDRC board. Embassy - Canada's foreign policy newspaper. April 9.

Sismondo, S. 2008. Science and technology studies and an engaged program. In Hackett, E.J., O. Amsterdamska, M. Lynch and J. Wajcman (eds.) The handbook of science and technology studies. Cambridge: MIT Press. Pp. 13-31.

Sparke, M. 2009. Unpacking economism and remapping the terrain of global health. In Kay, A. and O. Williams (eds.) Global health governance: crisis, institutions and political economy. Basingstoke: Palgrave MacMillan. Pp. 131-159.

Star, S.L. (ed.) 1995. Ecologies of knowledge: work and politics in science and technology. Albany, NY: SUNY Press.

Sundberg, J. and J. Dempsey. 2014. Political ecology. In Cloke, P., P. Crang and M. Goodwin (eds.) Introducing human geographies (3rd ed.). New York: Routledge. Pp. 175-186.

Tannock, S. 2010. Learning to plunder: global education, global inequality and the global city. Policy Futures in Education 8(1): 82-98.

Taylor, P.J. 1990. Mapping ecologists' ecologies of knowledge. PSA: Proceedings of the Biennial Meeting of the Philosophy of Science Association 1990 Volume 2: 95-109. DOI:10.1086/psaprocbienmeetp.1990.2.193061

Taylor, P.J. 2011. Agency, structuredness, and the production of knowledge within intersecting processes. In Goldman, M.J., P. Nadasdy and M.D. Turner (eds.) Knowing nature: conversations at the intersection of political ecology and science studies. Chicago: University of Chicago Press. Pp. 81-98.

Turner, M.D. 2014. Political ecology I: an alliance with resilience? Progress in Human Geography 38(4): 616-623. 
Walker, J. and M. Cooper. 2011. Genealogies of resilience: From systems ecology to the political economy of crisis adaptation. Security Dialogue 42(2): 143-160.

Walker, P.A. 2006. Political ecology: where is the policy? Progress in Human Geography 30(3): 382-395.

Waltner-Toews, D. 2001. An ecosystem approach to health and its applications to tropical and emerging diseases. Cadernos de Saúde Pública 17(Supp.): 7-22.

Waltner-Toews, D. and J. Kay. 2005. The evolution of an ecosystem approach: The diamond schematic and an Adaptive Methodology for Ecosystem Sustainability and Health. Ecology and Society 10(1): 38.

Webb, J.C., D. Mergler, M.W. Parkes, J. Saint-Charles, J. Spiegel, D. Waltner-Toews, A. Yassi and F. Woollard. 2010. Tools for thoughtful action: the role of ecosystem approaches to health in enhancing public health. Canadian Journal of Public Health 101(6): 439-441.

Wilcox, B.A., A.A. Aguirre, P. Daszak, P. Horwitz, P. Martens, M. Parkes, J.A. Patz and D. Waltner-Toews. 2004. EcoHealth: a transdisciplinary imperative for a sustainable future. EcoHealth 1(1): 3-5. 